\title{
Is Fiscal Adjustment More Durable When The IMF is Involved? ${ }^{1}$
}

\author{
ALEŠ BULÍr $\check{R}^{1} \&$ SOOJIN MOON ${ }^{2}$ \\ ${ }^{1}$ International Monetary Fund. E-mail: abulir@imf.org; \\ ${ }^{2}$ Department of Economics, University of California, Los Angeles, CA, USA. \\ E-mail:sjmoon@ucla.edu
}

\begin{abstract}
This paper investigates fiscal developments in 112 countries during the 1990s. It finds that while the overall fiscal balance improved in most of them, the composition of this improvement differed. In countries without IMF-supported programmes, revenues increased modestly and expenditure declined sharply, while in programme countries both post-programme revenue and expenditure declined. However, in countries with programmes that included fiscal structural conditions, the adjustment was effected primarily through sharp expenditure compression. No evidence of a statistically significant impact of IMF conditionality was found. Moreover, fiscal developments were influenced by cyclical factors and by the general stance of macroeconomic policies.
\end{abstract}

Comparative Economic Studies (2004) 46, 373-399. doi:10.1057/palgrave.ces.8100051

Keywords: IMF-supported programmes, conditionality, fiscal policy, general evaluation estimator

JEL Classifications: F33, H30

\section{INTRODUCTION}

What determines the composition of fiscal adjustment and does it differ between countries with IMF-supported programmes and those without such arrangements? Moreover, how effective is IMF structural conditionality for post-programme fiscal developments? This paper attempts to answer these

\footnotetext{
${ }^{1}$ The authors are indebted to Tim Lane and Alex Mourmouras for extensive discussions. We are also grateful for helpful comments from George Anayiotos, Martin Čihák, Christina Daseking, Kamil Dybczak, Gervan Fearon, Rex Ghosh, Sanjeev Gupta, Javier Hamann, Eduardo Ley, Paolo Mauro, Alex Segura Ubiergo, Kateřina Šmídková, Alun Thomas, Jaroslaw Wieczorek and two anonymous referees as well as participants at the 2002 Atlantic Economic Society conference, 2002 Czech Economic Society conference, 2003 International Institute of Public Finance conference, and seminar participants at the International Monetary Fund. Anna Ivanova kindly shared some data with us.
} 
questions by investigating the fiscal developments in 112 countries during the 1990s, some with and some without IMF-supported programmes.

A central objective of IMF-supported programmes has been to reduce external imbalances (International Monetary Fund, 1998). This often requires bringing the budget under control: first, fiscal profligacy often causes current account deficits and, second, even if the initial budgetary position is sustainable, additional fiscal tightening may be needed if the domestic currency comes under pressure (Ghosh et al., 2002). This adjustment has been part of broader medium-term macroeconomic programmes that also encompass supply side structural reforms relevant for external stability.

This paper examines post-programme fiscal developments in countries with and without an IMF-supported programme. It finds significant differences in the composition of adjustment between programme and nonprogramme countries as well as large differences among programme countries. In nonprogramme countries, revenue increased modestly and expenditure declined sharply, while in programme countries both revenue and expenditure declined during the post-programme period. Moreover, in IMF-supported programmes that included structural conditions, the adjustment was effected primarily through sharp expenditure compression in order to offset revenue declines. We did not find any evidence that fiscal structural conditions improved revenue performance after the end of the programme. Fiscal developments were strongly affected by the business cycle and, to some extent, by the general stance of macroeconomic policies.

This paper is organised as follows. First, we review the stylised facts and define the sample. Second, we describe the techniques used in our estimations. Third, we present and discuss our results. The final section concludes.

\section{IMF PROGRAMMES AND FISCAL DEVELOPMENTS}

\section{How to measure the impact of IMF-supported programmes?}

What is the impact of IMF-supported programmes on fiscal adjustment? In the literature, three different influences have been construed. One view is that these programmes provide external resources beyond the financing provided by the IMF itself to the extent that they have a catalytic effect; thus, adjustments take place at lower costs than in the absence of such an arrange ment (Cottarelli and Curzio, 2002). Hence, IMF-supported programmes can be associated with either smaller or larger fiscal deficits, depending on the nature of the shock and the design of the programme. This description is close to the official IMF view of its role (Dhonte, 1997; Haque and Khan, 1998; Bird, 2002; Bird and Rowland, 2002). A second view is that these programmes 
prescribe excessively fast adjustment, by uniformly requiring monetary tightening, expenditure cuts, and higher taxes, hurting both the poor and businesses in the process. A third view is that IMF-supported programmes delay fundamental reforms by merely treating the symptoms of financing needs by repeated lending to crisis-prone and structurally unstable countries (Bird, 1996).

Which view is the closest to reality? Empirical assessments of the impact of IMF-supported programmes are notoriously complex. Countries' macroeconomic performance is influenced by secular forces, external shocks, structural reforms, and temporary availability of IMF-linked financing. The initial conditions and exogenous shocks need to be separated from the effects of IMF-supported arrangements, because countries that do not undertake such programmes are not an appropriate control group for IMF-programme countries (Krueger, 1998). An appropriate technique is the general evaluation estimator (GEE), due to Goldstein and Montiel (1986), which constructs counterfactual economic policies first and then tests the importance of IMF-supported programmes. This approach was successfully tested, inter alia, by Khan (1990), Conway (1994), and Dicks-Mireaux et al. (2000).

The question asked is two-fold. First, what are the factors that lead to IMFsupported programmes? The answer to this question is well known: economic variables, such as the current account balance, inflation, international reserves, debt service, GDP per capita, and so on, together with participation in previous programmes explain reasonably well the approval of an IMFsupported arrangement (Conway, 1994; Knight and Santaella, 1997; Bird et al., 2000). Knight and Santaella (1997) found that policy commitments made by recipient governments matter for the programme approval as well; if the authorities promise stronger adjustment, the Fund is more likely to approve a bigger loan. Barro and Lee (2002) added to the list of variables a bigger IMF quota, more IMF professional staff of that country origin, and a closer political/economic connection to the major shareholders of the IMF. The last variable is intuitive - 'better connected' countries are likely to get more money with fewer strings attached (Bird, 2002). In contrast, the literature found no relationship between political economy variables (political institutions, quality of bureaucracy, and so on) and the participation in an IMF-supported programme. In other words, public sector policies are essentially the same in democracies and nondemocracies (Mulligan et al., 2003).

Second, and this is the question we are interested in, what are the macroeconomic effects of IMF-supported programmes? This strand of the literature has a few well-established stylised facts as well. IMF-supported programmes were found to be associated with an improved post-programme current account balance. Inflation slowed down and real growth recovered, however, typically by less than what was projected under the programme 
(Conway, 1994; Schadler et al., 1995; Bird, 2002; Ghosh et al., 2002). In contrast, Barro and Lee (2002) reported opposite results-participation in IMF-supported programme was found to lower growth and investment. Unfortunately, Barro and Lee controlled neither for the repeated use of Fund loans nor for country's adherence to the policies agreed in the programme. At the same time, limited work has been done on longer-term fiscal effects of IMF-supported programmes.

The macroeconomic effects of IMF-supported programmes depended, on the one hand, on borrowing countries' domestic political economy (Ivanova et al., 2003, Khan and Sharma, 2001; Boughton and Mourmouras, 2002) and, on the other hand, on the technical design of the programme (conditionality) or the amount of money borrowed (Schadler et al., 1995). Regarding the former, strong special interests, political instability, inefficient bureaucracies, lack of political cohesion, and ethno-linguistic divisions weakened programme implementation. Adjustment programmes were more successful in countries where they augmented home-grown reforms than in countries where the Fund and/or other donors tried to impose them on unwilling authorities. Regarding the latter, it seems that the impact of Fund conditionality was governed by a 'Laffer-curve' relationship, whereby a few, well-targeted conditions had a positive impact on economic performance, but too many or too intrusive conditions hindered such performance (Collier et al., 1997; Dollar and Svensson, 2000; Goldstein, 2000; Bird, 2001).

To this end, we will use the IMF's Monitoring of Fund Arrangements Database (MONA) that collects information on conditionality under IMFsupported programmes and which was first utilised in International Monetary Fund (2001). Surprisingly, assessments of structural conditionality have been rare and this paper is a first empirical exercise to address its role in macroeconomic adjustment in a systematic fashion.

\section{What is IMF conditionality?}

Conditionality is an explicit link between the approval (or continuation) of the Fund's financing and the implementation of certain aspects of the authorities' policy programme (Guitián, 1981). The conditions may be either quantitative (say, a limit on reserve money growth) or structural (say, the introduction of a value-added tax). ${ }^{2}$ In general, conditionality is designed to encompass policy measures that are critical to programme objectives or key internal data targets that sound warning bells if policies veer off track. Whereas in the mid-1980s structural conditionality in IMF-supported arrangements was rare, by the mid-1990s

\footnotetext{
${ }^{2}$ IMF-supported programmes typically do not stipulate quantitative fiscal conditions in terms of, say, the primary fiscal balance or domestic fiscal revenue.
} 
about half of all programmes included structural conditions. The average number of structural conditions per programme year increased from two in 1987 to more than 16 in 1997 (International Monetary Fund, 2001; Boughton, 2001).

These developments were the result of several forces. First, the IMF gradually placed more emphasis on supply-side reforms as compared to demand management. Second, the IMF's involvement in low-income and transition countries was focused on the alleviation of structural imbalances and rigidities prevalent in these economies (Mercer-Blackman and Unigovskaya, 2000). Finally, the experience with monetary and fiscal policies indicated that their success depends critically on structural conditions. Indeed, most structural conditions were in the core area of IMF expertise (International Monetary Fund, 2001).

In this paper, we focus on three main types of structural conditions tabulated in the MONA database: (i) prior actions, which are stipulated as preconditions to the approval of an IMF-supported programme, (ii) structural performance criteria, fulfilment of which is a formal precondition for programme continuation, and (iii) structural benchmarks, which are agreed with the authorities and monitored by the IMF staff, but are not a formal precondition for programme continuation. The majority of conditions were structural benchmarks, while structural performance criteria were the least numerous conditions. The extent of structural conditionality was in part determined endogenously - countries with a large reform agenda or history of poor reform performance tended to get more conditions, although no clear-cut answers as to why some countries have many more conditions than others are available (International Monetary Fund, 2001). If anything, distribution of structural conditions was correlated regionally and with the length of the programmes (quite predictably, 12-months IMF-supported programmes tend to have fewer supply side conditions than 3-year programmes).

All but two IMF-supported programmes with structural conditionality in our sample (33 countries during 1993-1999) contained at least one fiscal condition. ${ }^{3}$ Indeed, fiscal structural conditionality was the most common area of structural conditionality, comprising about 50 percent of all conditions. While most fiscal conditions were designed as neutral vis-à-vis the overall fiscal balance, some conditions were geared towards either higher revenue or lower expenditure. We classify all those measures according to their expected revenue or expenditure impact and present their summary in Table $1 .{ }^{4}$ Based

\footnotetext{
${ }^{3}$ Throughout the paper, we used a sample of 112 countries, of which 48 countries did not have a programme during the sample period, and 31 and 33 countries had programmes without and with structural conditions, respectively. See the fourth section for the list of countries.

${ }^{4}$ For example, we classified the 'introduction of ad valorem excise duties' as a revenueincreasing condition; a 'reduction in civil service positions' as an expenditure-lowering condition; and the 'adoption of accounting system of the Treasury' as a neutral condition.
} 
Table 1: Frequency of fiscal structural conditionality

\begin{tabular}{lcc}
\hline & ${\text { Total number of } \text { conditions }^{\mathrm{a}}}$ & Implementation ratio $^{\mathrm{b}}$ \\
\hline All conditions & 15.4 & 77.4 \\
Revenue conditions $^{\mathrm{c}}$ & 4.7 & 78.5 \\
Expenditure conditions $^{\mathrm{c}}$ & 1.8 & 81.3 \\
Neutral conditions $^{\mathrm{d}}$ & 8.7 & 71.4
\end{tabular}

Source: MONA; authors' calculations

${ }^{a}$ Sample average, per programme, not adjusted for programme length.

bample average, implemented conditions/total conditions, in percent.

${ }^{\text {c} C o n d i t i o n s ~ w i t h ~ i d e n t i f i e d ~ i m p a c t ~ o n ~ t h e ~ o v e r a l l ~ b a l a n c e . ~}$

${ }^{d}$ Revenue and expenditure conditions without a clear impact on the overall balance.

on IMF's country team assessments, close to four-fifths of all fiscal conditions were met.

\section{Some stylized facts about the fiscal developments in the 1990s}

Fiscal developments - beside the immediate, short-term impact of the IMFsupported programmes - are affected by the business cycle, political economy, and debt sustainability factors. First, the impact of cyclical conditions was strong in our sample - while pre-programmes real GDP grew on average by 1.5 percent in 1993-94, the rate more than doubled to almost 4 percent in 199799, after the end of IMF-supported programmes. Second, the components of the overall fiscal balance were public choice variables and voters decided how much tax they wanted to contribute and how they wanted the proceeds to be spent (Drazen, 2000; Mulligan et al., 2003). Third, debt sustainability constrained the fiscal stance: the deficits preferred by the electorate may not be financeable (Tanzi and Schuknecht, 1997 or Hansson and Stuart, 2003).

The fiscal balance improved in two-thirds of all countries by an average of 2 percentage points of GDP between the pre-programme and post-programme periods or between 1993 and 1999 for the nonprogramme countries (Figure 1 and Table 2). ${ }^{5}$ The magnitude of the post-programme fiscal improvement was not uniform, however, and nonprogramme countries improved their fiscal balances by more than programme countries: 3 and $\frac{1}{2}$ of a percentage points of GDP, respectively. ${ }^{6}$ Differences prevailed among programme countries: while nonstructural programme countries worsened their balances by some

\footnotetext{
${ }^{5} 1993$ and 1999 are the median dates in the sample of programme countries.

${ }^{6}$ We are aware of measurement problems. First, owing to data limitations, all fiscal balances are actual, cyclically nonadjusted observations as opposed to structural fiscal balances. Second, in recognition of the reporting weaknesses, IMF-supported programmes often broaden the definition of the fiscal balance, such as to include extrabudgetary expenditures or contingent liabilities, invariably implying a worsening of the headline fiscal balance. Unfortunately, historic series are not always fully adjusted.
} 
A Bulír \& S Moon

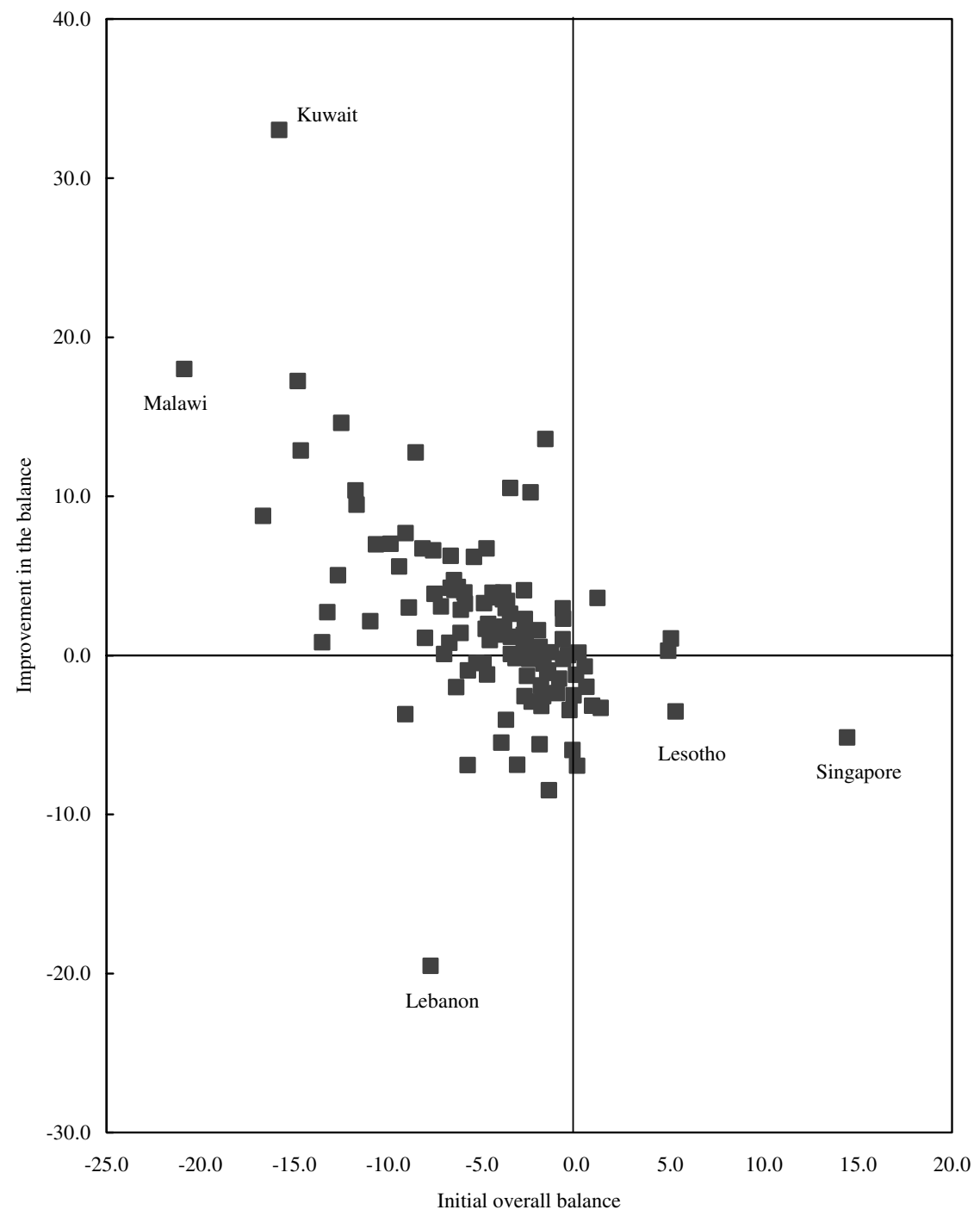

Figure 1: Change in the overall fiscal balance 3 years after the end of the IMF-supported programme or 1999 for nonprogramme countries, compared to the initial observation. The median initial observation is 1993 and the median end-period observation is 1999 (in percent of GDP, 112 countries).

Source: World Economic Outlook; authors' calculations.

2 percentage points of GDP, those with structural conditionality improved it by more than 3 percentage points of GDP. These findings are robust to the choice of the end-period observation: our results change little whether we assess them 1, 2, or 3 years after the end of the IMF-supported programme. 
Table 2: Change in fiscal outcomes 3 years after the end of IMF-supported programmes ${ }^{a}$ (in percent of GDP)

\begin{tabular}{|c|c|c|c|c|c|c|}
\hline & \multicolumn{2}{|c|}{ Overall balance } & \multicolumn{2}{|c|}{ Revenue and grants } & \multicolumn{2}{|c|}{$\begin{array}{l}\text { Expenditure and } \\
\text { net lending }\end{array}$} \\
\hline & Change & $\begin{array}{l}\text { Initial } \\
\text { balance }\end{array}$ & Change & $\begin{array}{l}\text { Initial } \\
\text { revenues }\end{array}$ & Change & $\begin{array}{c}\text { Initial } \\
\text { expenditures }\end{array}$ \\
\hline \multicolumn{7}{|l|}{ All countries } \\
\hline Average & 1.8 & -4.4 & -0.3 & 25.2 & -2.0 & 29.2 \\
\hline Median & 1.5 & -3.7 & 0.0 & 24.2 & -2.0 & 28.9 \\
\hline \multicolumn{7}{|c|}{ of which: } \\
\hline \multicolumn{7}{|c|}{ Nonprogramme countries ${ }^{b}$} \\
\hline Average & 3.2 & -4.5 & 0.4 & 27.0 & -2.8 & 31.5 \\
\hline Median & 2.4 & -3.7 & 0.3 & 27.2 & -2.6 & 31.5 \\
\hline \multicolumn{7}{|c|}{ Programme countries } \\
\hline Average & 0.4 & -4.2 & -1.0 & 23.4 & -1.2 & 27.0 \\
\hline Median & 0.5 & -3.7 & -0.5 & 20.6 & -0.8 & 24.7 \\
\hline \multicolumn{7}{|c|}{ Of which: } \\
\hline \multicolumn{7}{|c|}{ Without structural conditions } \\
\hline Average & -1.9 & -2.9 & -0.3 & 24.0 & 1.6 & 26.9 \\
\hline Median & -0.8 & -2.7 & 0.2 & 22.2 & 1.0 & 24.2 \\
\hline \multicolumn{7}{|c|}{ With structural conditions } \\
\hline Average & 3.7 & -6.3 & -2.1 & 22.6 & -5.2 & 27.1 \\
\hline Median & 2.6 & -5.9 & -1.5 & 19.3 & -4.7 & 25.4 \\
\hline
\end{tabular}

Source: World Economic Outlook; authors' calculations

${ }^{a}$ At 3 years after the end of the IMF-supported programme minus the pre-programme observation. ${ }^{b} 1999$ for nonprogramme countries. The median initial observation is 1993 and the median end-period observation is 1999 .

How was the fiscal adjustment achieved? First, revenue adjustment was much weaker than expenditure adjustment. Revenue and grants declined in programme countries and increased somewhat in nonprogramme countries. The difference could not be accounted for by either lowering of trade taxes or lower aid receipts. Regarding the former, we did not find any quantitative link between changes in trade taxes and revenues. Regarding the latter, the contribution of grants is too small to account for the fall in the aggregate variable (Bulîr and Hamann, 2003). Second, the expenditure compression was strong in nonprogramme and structural programme countries (by 3 and 5 percentage points of GDP), while in nonstructural programme countries postprogramme expenditures expanded by $1 \frac{1}{2}$ percentage points of GDP.

The variability of programme country results suggests that we control for exogenous and programme-specific factors. First, the initial fiscal deficits in nonstructural programme countries were smaller than those in structural programme countries and presumably did not pose such a threat to 
A Bulír \& S Moon

Table 3: Selected characteristics of programme and nonprogramme countries

\begin{tabular}{|c|c|c|c|c|c|c|c|}
\hline & \multicolumn{5}{|c|}{ Pre-programme developments } & \multirow{2}{*}{$\begin{array}{l}\text { Programme } \\
\text { stoppage }^{\mathrm{e}}\end{array}$} & \multirow{2}{*}{$\begin{array}{l}\text { Post- } \\
\text { programme } \\
\text { real GDPd,f }\end{array}$} \\
\hline & $\begin{array}{l}\text { GDP per } \\
\text { capita }^{a, b}\end{array}$ & $\begin{array}{l}\text { Current } \\
\text { account }^{a, c}\end{array}$ & $\begin{array}{l}\text { Real } \\
\text { GDP }^{\mathrm{a}, \mathrm{d}}\end{array}$ & $\begin{array}{l}\text { Terms of } \\
\text { trade }^{a, d}\end{array}$ & Inflation $^{a, d}$ & & \\
\hline \multicolumn{8}{|l|}{ All countries } \\
\hline Average & 6,882 & -4.4 & 1.5 & 0.8 & 229.0 & n.a. & 3.9 \\
\hline Median & 1,954 & -2.8 & 2.7 & 0.4 & 11.2 & n.a. & 3.5 \\
\hline \multicolumn{8}{|c|}{ of which: } \\
\hline \multicolumn{8}{|c|}{ Nonprogramme countries } \\
\hline Average & 12,751 & -2.3 & 3.9 & 0.9 & 6.1 & n.a. & 3.6 \\
\hline Median & 12,772 & -1.2 & 3.3 & 0.1 & 2.9 & n.a. & 3.1 \\
\hline \multicolumn{8}{|c|}{ Programme countries } \\
\hline Average & 1,134 & -6.6 & -0.7 & 0.6 & 447.3 & 57.1 & 4.1 \\
\hline Median & 774 & -3.6 & 1.5 & 0.5 & 23.9 & n.a. & 3.7 \\
\hline \multirow{2}{*}{\multicolumn{8}{|c|}{$\begin{array}{l}\text { Of which: } \\
\text { Without structural conditions }\end{array}$}} \\
\hline & & & & & & & \\
\hline Average & 1,511 & -7.6 & -1.5 & 2.0 & 610.2 & 48.3 & 3.5 \\
\hline Median & 1,239 & -3.2 & 1.2 & 0.5 & 28.1 & n.a. & 4.1 \\
\hline \multicolumn{8}{|c|}{ With structural conditions } \\
\hline Average & 587 & -5.2 & 0.4 & -1.5 & 211.1 & 70.0 & 5.0 \\
\hline Median & 367 & -3.9 & 2.8 & 1.0 & 19.9 & n.a. & 3.5 \\
\hline
\end{tabular}

Source: World Economic Outlook, MONA; authors' calculations

${ }^{a}$ Average for 1993-94.

${ }^{\text {bIn }} 1995$ US dollars.

${ }^{\mathrm{c}}$ In percent of GDP.

dPercentage change.

ePre-programme stoppage occurs if either (i) the scheduled programme review was not completed or (ii) all scheduled reviews were completed but the subsequent annual arrangement was not approved. If a country had more than one programme during this period, one stoppage over-rides one or more successes.

fAverage for 1997-99 for nonprogramme countries.

macroeconomic stability (Table 2). Second, the nature of the initial disequilibrium differed across countries: in nonstructural programme countries, GDP declined more sharply prior to the programme and their rates of inflation and GDP per capita were higher (Table 3). Third, structural conditionality programmes had a higher incidence of programme interruptions. ${ }^{7}$ Finally, programmes that did not include structural conditions

${ }^{7}$ More conditions required for programme continuation increase the risk of missing some of them, however, missing one of them does not stop a programme. Providing the macroeconomic programme remained on track, the missed condition would likely be waived, the likelihood of waivers being positively related to the political clout of individual countries (Bird, 2002). 
were mostly short-term in nature, typically stand-by arrangements (SBA). In contrast, structural conditions were mostly applied in the context of the enhanced structural adjustment facility, which was succeeded by the poverty reduction and growth facility (ESAF and PRGF, respectively), or the Extended Fund Facility (EFF).

\section{SPECIFICATION OF THE MODEL}

Fiscal developments are affected by various exogenous and country-specific effects and, therefore, we re-examine them in multivariate panel and crosscountry regressions. The econometric investigation of the role of IMFsupported programmes has traditionally been motivated by the following question: 'Did the involvement of the IMF significantly improve the macroeconomic outcomes relative to what they would have been in the absence of an IMF-supported programme?' Most researchers answered this question in a model in which macroeconomic outcomes, such as inflation or external balance, $y$, were described as a function of: (a) macroeconomic policies that would have been observed in the absence of an IMF-supported programme, $x$; (b) exogenous variables, such as terms-of-trade shocks or wars, and political economy variables, such as the stability of the government, $w$; (c) the existence of an IMF-supported programme (usually a dummy variable, $d^{\mathrm{IMF}}$, equal to one if a Fund programme is in place and zero otherwise); (d) random shocks, $\varepsilon$ :

$$
y_{i j}=\beta_{0 j}+\beta_{j k} x_{i k}+\alpha_{j h} w_{i h}+\phi_{j} d_{i}^{\mathrm{IMF}}+\varepsilon_{i j}
$$

where $y_{i j}$ is the jth target variable in country $i$, and $x_{i k}$ and $w_{i h}$ are $k$ - and $h$ element vectors, respectively. For the jth target variable, $\beta_{j k}$ and $\alpha_{j h}$ are $k \times 1$ and $h \times 1$ vectors, respectively, of fixed parameters. If the parameter $\phi$ was found to be statistically significant, then it was said that IMF-supported programmes had macroeconomic effects. ${ }^{8}$

The simple model above has two drawbacks. First, 'macroeconomic policies in the absence of an IMF-supported programme' is an unobservable variable that has to be constructed in an ad hoc fashion. Second, the additive character of the IMF programme dummy can result in observational equivalence. For example, an identical macroeconomic outcome can be achieved because of the confidence effect of a programme, a cumulative

\footnotetext{
${ }^{8}$ The estimates of $\phi$ could suffer from simultaneous equation bias: participation in IMFsupported programmes depended on past policies (Conway, 1994, 2000; Przeworski and Vreeland, 2000; Barro and Lee, 2002) and an OLS regression of (1) would underestimate the true effect of Fund programmes.
} 
impact of policies and IMF financing (the catalytic effect of a programme), or structural reforms.

The key empirical issue in equation (1) is the formulation of policies adopted in the absence of Fund involvement $\left(x_{i k}\right)$. These policies can be observed only for nonprogramme countries and a counterfactual has to be estimated for programme periods. Goldstein and Montiel (1986) suggested constructing a policy reaction function linking the changes in macroeconomic policies, $\Delta x_{i k}$, to the deviations of observed lagged outcomes, $y_{i j(-1)}$, from their target values, $y_{i j}^{*}$. The policy reaction function may also contain lagged exogenous variables, $w_{i h}$, that the authorities would take into account in designing their policies:

$$
\Delta x_{i k}=\gamma_{k j}\left[y_{i j}^{*}-y_{i j(-1)}\right]+\delta_{i h} w_{i h(-1)}+\eta_{i k}
$$

where matrix $\gamma_{\mathrm{kj}}$ describes the speed of adjustment of policy instruments to disequilibria in the target variables. In estimating such a policy reaction function, researchers make two simplifying assumptions. First, the programme countries' counterfactual policies are identical to policies of nonprogramme countries. Second, the programme countries' shocks are comparable to those in nonprogramme countries.

Substituting equation (2) into equation (1) to eliminate the unobservable values of $x_{i k}$ and subsuming $y_{i j}^{*}$ in the constant, the usual specification of the GEE becomes

$$
\begin{aligned}
\Delta y_{i j}= & \beta_{0 j}-\left(\beta_{j k} \gamma_{k j}+1\right) y_{i j(-1)}+\beta_{j k} x_{i k(-1)} \\
& +\alpha_{j h} w_{i h}+\beta_{j k} \delta_{i h} w_{i h(-1)}+\phi_{j} d_{i}^{\mathrm{IMF}}+\left(\varepsilon_{i j}+\beta_{j k} \eta_{i k}\right)
\end{aligned}
$$

Our modification of the GEE model is three-fold. We attempted to separate the impact of (i) the country's performance under the programme, (ii) structural conditionality, and (iii) 'too many' structural conditions.

First, we augmented the Fund-programme variable to reflect the compliance with all programme conditions in an interactive dummy, $\tilde{d}^{\mathrm{IMF}}$. Successful programmes were defined as those that either disbursed all committed resources without interruptions or those that were designed and executed as precautionary arrangements (following the definition of programme success in Ivanova et al., 2003). A statistically significant parameter would indicate that the IMF's emphasis on programme implementation has some bearings for post-programme performance.

Second, and this is the main contribution of this paper, we separated out the role of fiscal structural conditionality. We tested whether the presence and/or implementation of Fund fiscal structural conditionality led to fiscal outcomes that were statistically different from those without such 
conditionality. There was no need to establish counterfactual structural policies: similar fiscal structural reforms were introduced irrespective of the presence of an IMF-supported programme. To this end, we introduced a set of variables, $c$, into equation (3) to test the significance of fiscal structural conditionality. These variables were defined either as a duration-adjusted count of fiscal structural conditionality; a ratio of implemented structural conditions to all fiscal structural conditions; or as a simple dummy variable. As in Table 1, we identified these variables as revenue increasing or expenditure lowering, and so on.

Third, we experimented also with a simple count of all structural conditions, $t^{\mathrm{TC}}$, to test for the argument that too many structural conditions are counterproductive. In countries where 'reform ownership' was low, a large number of structural conditions could indicate that the IMF staff tried to substitute the lack of a reform drive with additional, detailed conditionality and we would expect a worse post-programme fiscal performance in those countries. ${ }^{9}$

Formally, the reduced GEE equation became

$$
\begin{aligned}
\Delta y_{i j}= & \beta_{0 j}-\left(\beta_{j k} \gamma_{k j}+1\right) y_{i j(-1)}+\beta_{j k} x_{i k(-1)} \\
& +\alpha_{j h} w_{i h}+\beta_{j k} \delta_{i h} w_{i h(-1)}+\phi_{j} \tilde{d}_{i}^{\mathrm{IMF}}+\psi_{j} c_{i}^{\mathrm{SC}} \\
& +\theta_{j} \mathrm{t}_{i}^{\mathrm{TC}}+\left(\varepsilon_{i j}+\beta_{j k} \eta_{i k}\right)
\end{aligned}
$$

What are the expected signs of the variables pertaining to IMF conditionality? First, although the fiscal position during the programme was indeterminate, in the medium run, those programmes were geared towards sustainable fiscal positions. Hence, $\phi$ should be positive, in particular if the programme was declared as 'successful'. Second, $\psi$ should be associated with an improvement in the fiscal balance: we have identified structural measures that should ceteris paribus either increase revenue or lower expenditure. Finally, the expected sign of $\theta$ was negative: an excessive number of conditions would derail the reforms.

\section{SAMPLE SELECTION AND ESTIMATION}

We estimated the model in three steps. First, using data for nonprogramme countries only, we estimated the policy reaction function (equation (2)) for the relevant macroeconomic variables. ${ }^{10}$ Second, using the estimated

\footnotetext{
${ }^{9}$ There are a few well-known exceptions, though. For example, Bulgaria in 1997 insisted on a detailed specification of structural conditionality in order to avoid domestic political confrontation about the design of reforms (International Monetary Fund, 2001).

${ }^{10}$ The alternative is to estimate the policy reaction function for programme countries before IMF arrangements. This approach has two disadvantages. First, countries pursue 'bad' policies in the run-up to the IMF-supported programme. Second, for some of the repeated users of Fund resources, it is difficult to find long enough periods of pre-programme policies.
} 
parameters, we simulated macroeconomic policies in programme countries to reflect what those policies would have been in the absence of an IMFsupported programme. Hence, the vector of policies, $x_{i k}$, comprised actual observed policies in nonprogramme countries and counterfactual policies in programme countries. Third, we estimated the GEE equation (equation (4)) for both programme and nonprogramme countries, capturing the impact of IMF-supported programmes and structural conditionality residually.

We selected the 1993-96 period because of three considerations. First, this 4-year period followed the IMF membership of transition economies in 1991-92, but preceded the 'Asian' crisis of 1997-98. Second, during this period the IMF was deeply involved in structural reforms in less developed economies. Third, we needed 3 years of after-programme data for the GEE estimation, which made 1996 the latest permissible cutoff point in our sample.

\section{The policy reaction function}

The policy reaction function determined the stance of monetary, external, and incomes policies, respectively, as a function of the pre-announced fiscal adjustment. The fiscal targets, $y_{i j}^{*}$, were derived from 1-year-ahead world economic outlook (WEO) projections based on the annual policy discussions between the authorities and IMF staff, which reflect the authorities' pre-announced policy stance for the period ahead. ${ }^{11}$ The difference between this projection and the current fiscal outcome, $y_{i j(-1)}$, then measured the fiscal disequilibrium to which the authorities reacted with changes in policy instruments in the coming year. We saved the estimated coefficients from the policy reaction function, and used them to simulate counterfactual policies in programme countries. Three policy variables, $x_{i k}$, were used: (i) the ex post real interest rate (the representative nominal interest rate minus the consumer price index (CPI)); (ii) the nominal effective exchange rate (NEER); and (iii) the current account balance as a percentage of GDP (see Table 4 for definitions and sources).

The endogenous policy variables were initially regressed on a wide vector of explanatory variables that was - using the general-to-specific approach narrowed eventually to five variables: (i) the change in the overall fiscal balance in percent of GDP $\left(\Delta y_{i j}\right)$; (ii) the terms-of-trade index; (iii) the oil price (the international crude oil price in US dollars); (iv) the political cohesion index (a measure of political stability); and (v) an OECD intercept dummy (unity for countries that are members of the Organization for Economic Cooperation and Development, and zero otherwise). Table 5 summarises these results.

\footnotetext{
${ }^{11}$ More complex alternatives could, for example, derive the targeted fiscal balance from a sustainable debt trajectory (Bohn, 1998) or medium-term fiscal rules (Scott, 1996).
} 
Table 4: Definitions of variables

\begin{tabular}{|c|c|c|}
\hline Variable & Description & Source ${ }^{a}$ \\
\hline Overall balance & Change from the pre-programme year; in percent of GDP & WEO \\
\hline \multicolumn{3}{|l|}{ Revenue and grants } \\
\hline \multicolumn{3}{|l|}{ Expenditure and net lending } \\
\hline Real GDP growth & $\begin{array}{l}\text { Gross domestic product at constant prices; year-on-year } \\
\text { change in percent }\end{array}$ & WEO \\
\hline GDP per capita & Gross domestic product in constant US dollars & WEO \\
\hline Aid-to-GDP ratio & External aid; change from the pre-programme period & WDI \\
\hline Inflation rate & $\begin{array}{l}\text { Consumer price index (CPI); year-on-year change in } \\
\text { percent }\end{array}$ & WEO \\
\hline Terms of trade & $\begin{array}{l}\text { Terms of trade of goods and services; year-on-year } \\
\text { change in percent }\end{array}$ & WEO \\
\hline Index of political cohesion & $\begin{array}{l}\text { This variable measures if one party controls both the } \\
\text { legislative and executive branches of the government }\end{array}$ & DPI \\
\hline Programme stoppage & $\begin{array}{l}\text { Programme stoppage occurs if either (i) the scheduled } \\
\text { programme review was not completed or (ii) all } \\
\text { scheduled reviews were completed but the subsequent } \\
\text { annual arrangement was not approved. }\end{array}$ & IMMA \\
\hline Current account balance & $\begin{array}{l}\text { Current account balance; estimated from the policy } \\
\text { reaction function for programme countries, actual data } \\
\text { for nonprogramme countries; in percent of GDP }\end{array}$ & WEO \\
\hline $\begin{array}{l}\text { Nominal effective } \\
\text { exchange rate }\end{array}$ & $\begin{array}{l}\text { NEER; estimated from the policy reaction function for } \\
\text { programme countries, actual data for nonprogramme } \\
\text { countries; change from the pre-programme period in } \\
\text { percent }\end{array}$ & WEO \\
\hline Real interest rate & $\begin{array}{l}\text { Ex post real money market interest rate; deflated by the } \\
\text { CPI; estimated from the policy reaction function for } \\
\text { programme countries, actual data for nonprogramme } \\
\text { countries; in percent }\end{array}$ & IFS \\
\hline IMF programme dummy & $\begin{array}{l}1 \text { if the country had an IMF-supported programme } \\
\text { during } 1993-96,0 \text { otherwise }\end{array}$ & MONA \\
\hline Measures (count) & $\begin{array}{l}\text { Number of fiscal measures (narrowly or broadly defined) } \\
\text { adjusted for programme duration }\end{array}$ & MONA \\
\hline Measures (implementation) & $\begin{array}{l}\text { Number of implemented fiscal measures (narrowly or } \\
\text { broadly defined) adjusted for programme duration }\end{array}$ & MONA \\
\hline
\end{tabular}

${ }^{a}$ The abbreviations stand for the following data sources, respectively: World Economic Outlook; World Development Indicators; Database of Political Institutions, Version 3.0 (World Bank, 2001); Ivanova et al. (2003); International Financial Statistics; and the Monitoring of Fund Arrangements Database.

The estimated coefficients were statistically significant and corresponded to basic intuition: higher fiscal deficits were associated with higher current account deficits; improvements in the terms of trade with narrower current account deficits; looser fiscal policy with tighter monetary policy; developed countries tended to have lower real interest rates; and so on. Only one political economy variable was significant, indicating that if one party controlled the government, current account balance was more likely to improve and vice versa. ${ }^{12}$

${ }^{12}$ Although we tested more than 10 political economy variables, all but one were eliminated using the general-to-specific approach used to arrive at a parsimonious version of the policy reaction 
Table 5: Estimates of the policy reaction function (heteroscedasticity-consistent, feasible GLS regression estimates, $t$-statistics in parentheses) ${ }^{a}$

\begin{tabular}{lcrc}
\hline Dependent variable & \multicolumn{1}{c}{$\begin{array}{c}\text { Current } \\
\text { account balance }\end{array}$} & NEER & Real interest rate \\
\hline Overall fiscal balance $\left(y_{t}^{*}-y_{t-1}\right)$ & $\begin{array}{c}0.21346^{* * *}(6.10) \\
-0.00005^{* *}(2.05)\end{array}$ & $\begin{array}{r}4.56403^{* * *}(2.59) \\
-0.11601^{* * *}(3.50)\end{array}$ & $\begin{array}{r}-3.59938^{* *}(2.50) \\
-0.01507^{*}(1.64) \\
0.11747^{* *}(2.31)\end{array}$ \\
$\begin{array}{l}\text { Terms of trade } \\
\text { International oil prices }\end{array}$ & $0.00170^{* *}(2.30)$ & & \\
Political cohesion & & & $-1.12769^{* *}(5.34)$ \\
Dummy for OECD membership & & $13.35^{* *}$ & $61.96^{* * *}$ \\
Wald test of joint parameter & $43.08^{* * *}$ & & -630.634 \\
$\quad$ significance $\left(\chi^{2}\right)$ & 667.0774 & -1012.315 & 288
\end{tabular}

Source: Authors' estimates

Note: All variables, except the OECD dummy, are in first differences.

${ }^{a}$ The superscripts $* * *,{ }^{* *}$, and $*$ denote the rejection of the null hypothesis that the estimated coefficient is zero at the 1,5 , and 10 percent significance levels, respectively.

The estimation was for the period 1992-97 with data for 48 countries that did not have a Fund-supported programme during the 1991-97 period, or 2 years prior to 1991: Australia, Austria, The Bahamas, Bahrain, Belgium, Belize, Botswana, Canada, China, Colombia, Cyprus, Denmark, Fiji, Finland, France, Germany, Greece, Grenada, Hong Kong SAR, Ireland, Israel, Italy, Japan, Kuwait, Lebanon, Maldives, Malta, Mauritius, Myanmar, Netherlands, New Zealand, Norway, Oman, Paraguay, Portugal, Qatar, Samoa, Singapore, Solomon Islands, South Africa, Spain, St. Lucia, Swaziland, Sweden, Switzerland, United Kingdom, United States, and Vanuatu. The sample is heterogeneous, capturing two extremes of IMF membership: a group of industrialised countries that graduated from Fund programmes in the early 1970s and a group of small economies that either obtained external financing outside of the Fund or did not need it.

\section{The generalized evaluation estimator}

We consider three target variables $\left(y_{i j}\right)$ measuring fiscal developments: (i) the overall central government balance; (ii) central government revenue and grants; and (iii) central government expenditure and net lending, all expressed in percent of GDP, in 64 countries that operated under IMFsupported programmes ${ }^{13}$ and 48 nonprogramme countries during 1993-96.

function. In some sense, this result was to be expected - in a forward-looking policy reaction function, the authorities would not base their policies on noneconomic forces outside of their control.

${ }^{13}$ The following 31 countries' IMF-supported programme did not contain any structural conditions: Azerbaijan, Belarus, Congo, Republic of, Costa Rica, Croatia, Czech Republic, 
While the first target variable is intuitively preferable to the other variables as a measure of the fiscal stance, revenue and expenditure regressions are useful checks of government policies. The endogenous policy variables stemmed from the policy reaction function and the exogenous variables were 2-year averages, lagged one period: the terms of trade, GDP per capita in constant US dollars, foreign aid in percent of GDP, the rate of inflation, and real GDP growth. ${ }^{14}$ Given the inclusion of the pre-programme fiscal observation, the model in levels can be rewritten into one with the dependent variables in first differences, with identical parameters.

This paper is primarily interested in the long-term effects of IMFsupported programmes, knowing that in the short run, fiscal developments could be affected by temporary budgetary adjustment in the context of an IMF-supported arrangement, with little or no long-term consequences. ${ }^{15}$ We wanted to measure the impact of IMF-supported programmes beyond the initial, short-term impact and, hence, we considered fiscal variables 1, 2, and 3 years after the initial programme ended, with 112, 109, and 97 observations, respectively. For example, if a country had a 3-year programme from January 1993 to December 1995, our fiscal variables in the 1-, 2-, and 3-year GEE estimation were dated 1996, 1997, and 1998, respectively, with a pre-programme observation of 1992. Thus, we compared programme periods of different length: the time span between the pre-programme and first post-programme observations was as short as 2 years (12-month stand-by arrangement) and as long as 4 years (3-year enhanced structural adjustment

Dominican Republic, Egypt, El Salvador, Estonia, Georgia, Haiti, Hungary, Jordan, Kazakhstan, Latvia, Lesotho, Macedonia, FYR, Mexico, Moldova, Nicaragua, Panama, Peru, Philippines, Poland, Romania, Sierra Leone, Slovak Republic, Turkey, Uganda, and Uzbekistan. The following 33 countries' programmes contained structural conditions (with the number of fiscal conditions in parentheses): Albania (10), Algeria (3), Benin (8), Bolivia (8), Bulgaria (0), Burkina Faso (14), Cambodia (16), Cameroon (5), Central African Republic (7), Chad (10), Côte d'Ivoire (8), Ecuador (1), Equatorial Guinea (4), Gabon (1), Ghana (8), Guinea-Bissau (11), Guyana (3), Kenya (4), Kyrgyz Republic (9), Lao People’s Democratic Republic (10), Lithuania (0), Malawi (8), Mauritania (13), Mongolia (3), Niger (1), Pakistan (4), Papua New Guinea (5), Russian Federation (2), Senegal (8), Togo (6), Ukraine (1), Vietnam (3), and Zambia (4).

${ }^{14}$ We did not include political economy variables in the GEE regression because of potential simultaneity bias: domestic politics is likely to have an impact on domestic GDP growth or aid receipts, but these variables were already included in our regressions.

${ }^{15}$ Gupta et al. (2002) reported that the probability of a reversal in fiscal adjustment was as high as 70 percent at the end of the second post-programme year for low-income countries. Three possible explanations are available for this finding. First, poor fiscal discipline or a lack of programme ownership may have caused the reversal. Second, the initial fiscal tightening could have been excessively tight, necessitating a subsequent fiscal stimulus. Finally, the initial adjustment may have been a mirage: the fiscal authority ran arrears vis-à-vis its suppliers, improving its reported cash balance and worsening its (unreported) accrual balance. 
facility with delayed reviews). For nonprogramme countries, we used 199799 data and a 2-year average for the 'pre-program' period in 1991-92.

\section{Results in the full sample}

In general, we find that cyclical variables drove the fiscal developments and that the impact of macroeconomic policy variables was comparatively small (Tables 6-8). ${ }^{16}$ In all cases, the robust estimators were the autoregressive terms, real GDP growth, and the real rate of interest, the stance of monetary policy being a good measure of the general tightness of macroeconomic policies. In some cases, we also found inflation, and certain conditionality variables to be significant. The dummy measuring programme participation was statistically insignificant, implying that past IMF-supported programmes did not make the medium-term fiscal adjustment either softer or stronger - on average, programme countries adjusted as much as nonprogramme countries. Countries in programmes without interruptions adjusted somewhat more, but these results were not statistically significant.

The lack of in-sample variability in the structural conditionality variables and their overall substitutability suggest that these variables operated more like an intercept dummy variable as opposed to a slope coefficient. Unlike Ivanova et al. (2003), who looked at performance during IMFsupported programmes, we did not find any statistically significant postprogramme impact of the political stability variables (political cohesion and ethnic fractionalization, type of government, and so on). Neither did we find any systematic impact of the type of IMF-supported programme, its length, or the repeated use of IMF credit. The only statistically significant regional dummy was the sub-Saharan Africa dummy.

\section{The overall balance}

The change in the post-programme overall balance was predicted reasonably well by the pre-programme overall balance (a bigger initial deficit was associated with a bigger improvement), lagged GDP growth (faster growth improved the balance), and the level of development (countries with higher GDP per capita improved their overall balance by more than countries with low GDP per capita); see Table 6. These variables accounted for almost all of the explained variance of the dependent variable (50-60 percent).

Several other variables were either marginally significant or significant only in some regressions. One of them was the aid-to-GDP ratio, indicating

${ }^{16}$ We present both full-blown and parsimonious estimates with statistically significant variables only. See Bulír and Moon (2003) for detailed regression results. 


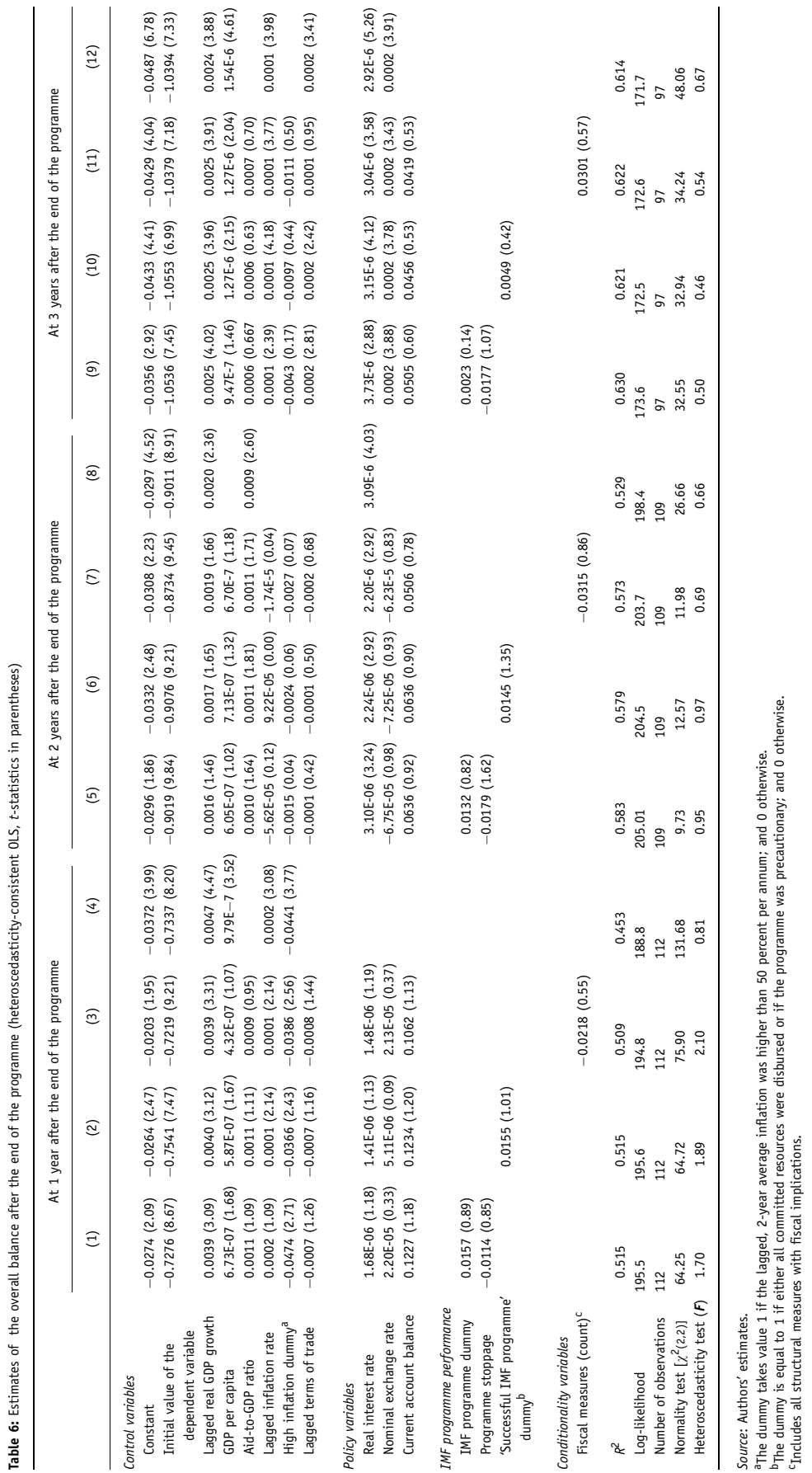


A Bulír \& S Moon 弪

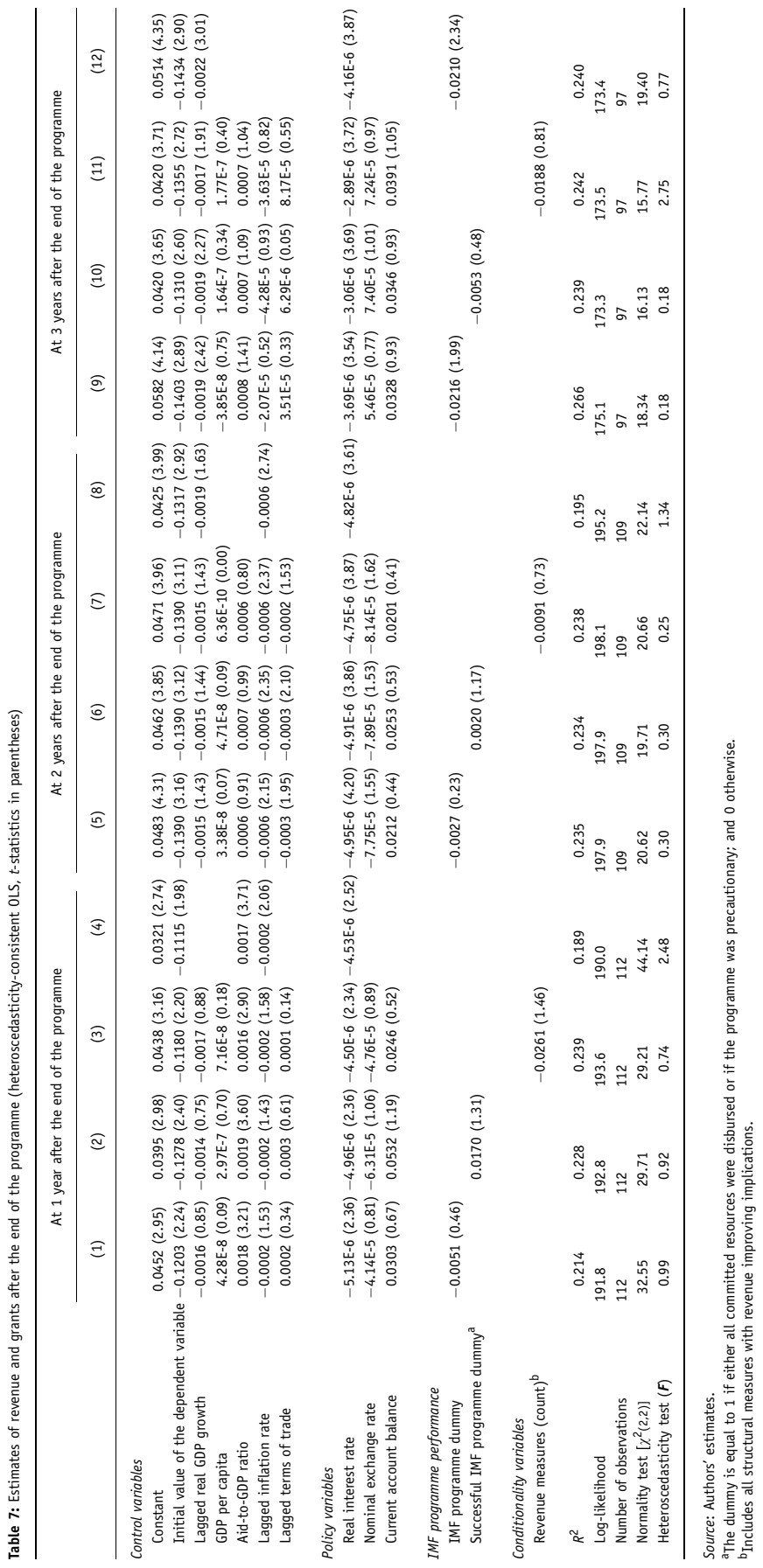




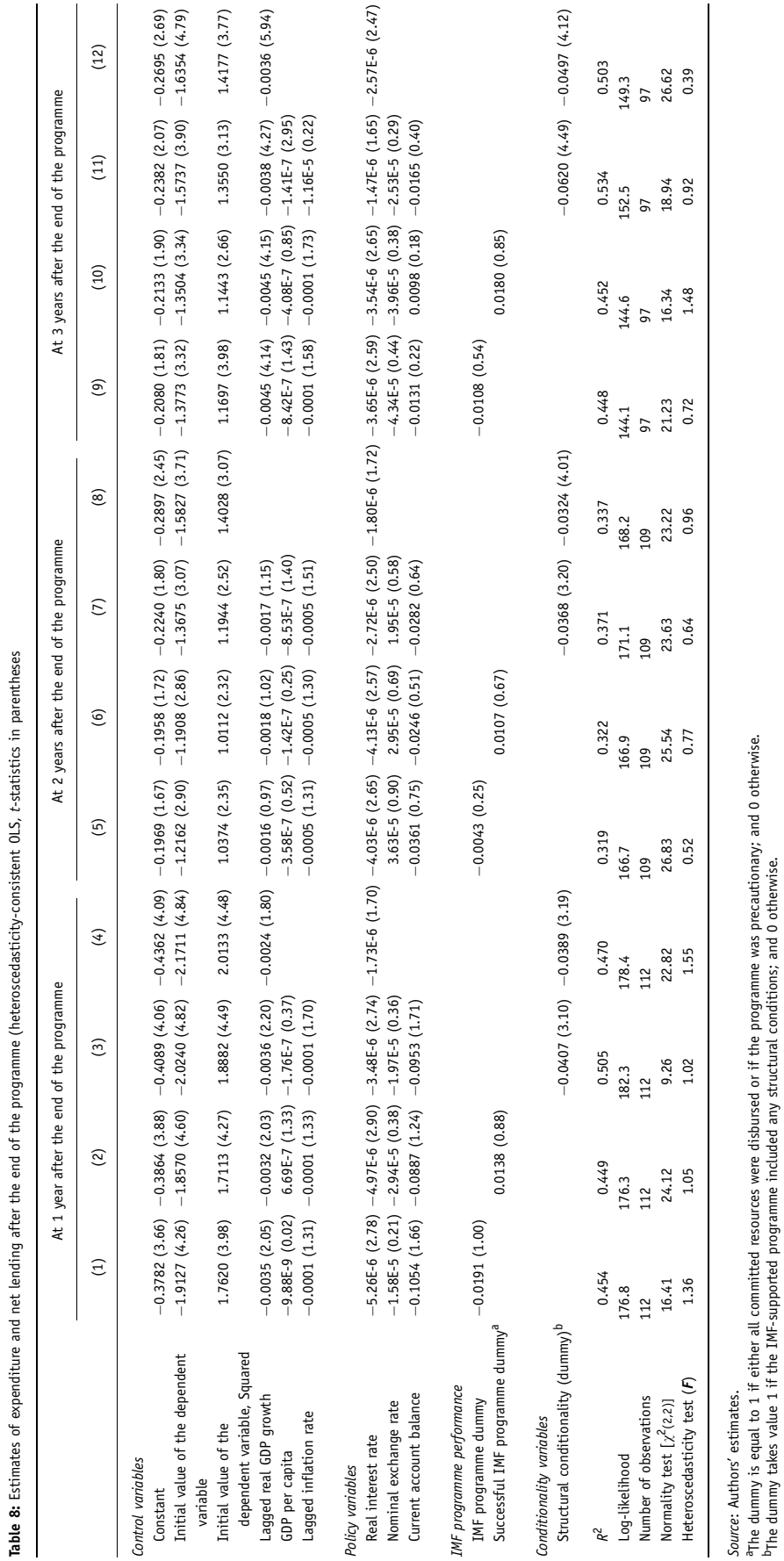


some stabilising impact of foreign aid inflows. ${ }^{17}$ Moderate inflation was associated with improvements in the overall balance, while countries with an average annual inflation of more than 50 percent worsened their fiscal position. Countries with tighter monetary policies had a stronger improvement in their overall balances, presumably as a result of generally tighter macroeconomic policies. The IMF programme performance variables were statistically insignificant for the post-programme period, although the signs of their parameters were intuitive. Countries with programme stoppages did worse than the average, while those without interruptions did better. The conditionality variables were all insignificant, with changing parameter signs.

\section{Revenue and grants}

Revenue regressions explained much less of the variance of the dependent variable (20-30 percent), even though the results were also dominated by the pre-programme revenue levels and cyclical effects (Table 7). The revenue-toGDP ratio worsened in countries with larger-than-average initial revenue and it was inversely related to real GDP growth. Both results were intuitive: on the one hand, the tax burden peaked in many countries in the late 1980s and, on the other hand, fast-growing economies did not need to increase their tax-toGDP ratio.

The aid-to-GDP ratio was positive, but statistically insignificant in all but the 1-year-after-the-programme estimates. ${ }^{18}$ Inflation worsened revenue in most regressions - presumably through the Tanzi-Oliveira collection lag and no nonlinearity in the inflationary impact was found. The real interest rate was significant and negative, indicating that tight macroeconomic conditions were not conducive to revenue collection.

We did not find any statistically significant impact of IMF-supported programmes, although the parameter signs were consistently negative. Good performance under the programme was linked to improved revenue collection by some 2 percent of GDP, but this marginally significant effect disappeared the third year after the programme. All but one variable describing the quantity of structural measures were statistically insignificant, although they all came with negative signs. The latter results suggest that revenue-enhancing measures, and perhaps also technical assistance provided

\footnotetext{
${ }^{17}$ The improvement in the overall balance was partly tautological, because total revenues included grants, a part of foreign aid.

${ }^{18}$ Some authors argued that foreign aid causes longer-term fall in revenue by breeding corruption and creating a perverse motivation for the authorities not to collect taxes (Ziegler, 1996). Similarly, political economy models were mostly skeptical about the revenue increasing role of aid (Bulow and Klemperer (1999) or Tornell and Lane (1999).
} 
to programme countries, failed to provide a sustainable increase in the revenue-to-GDP ratio.

\section{Expenditure and net lending}

The variance of the expenditure-to-GDP ratio was mostly explained by preprogramme expenditure levels, the real rate of growth, and monetary policy (20-30 percent) (Table 8). Unlike in previous regressions, we found strong nonlinearity vis-à-vis the lagged dependent variable, past expenditure-to-GDP ratios: the expenditure-to-GDP ratio declined in countries with lower-thanaverage pre-programme expenditure ratios, but increased in countries with higher-than-average levels thereof. ${ }^{19}$ The former group comprised mostly poorer countries with structural conditionality programmes, while the latter group comprised richer countries with nonstructural conditionality. Countries that grew faster and those with tight monetary policies also lowered their expenditure-to-GDP ratios.

We did not find any statistically significant impact of IMF-supported programmes on expenditure developments. The structural conditionality variables were negative and significant, suggesting relative expenditure compression in countries with a structural conditionality of 2 percentage points of GDP or more. It is problematic to distinguish whether expenditures that were cut were wasteful (Gupta et al., 2002) or whether the compression was excessive (International Monetary Fund, 1996). We can only conjecture that the gradually increasing value of the structural conditionality parameter points to the former explanation, as expenditure compression accelerated after the end of the Fund arrangement. This observation is also consistent with a substantial body of evidence that social and capital spending was protected during the programme existence (Abed et al., 1998).

\section{Are countries with programmes containing structural conditionality 'different'?}

The finding that conditionality variables were insignificant for all but the expenditure regressions is puzzling. We do not see a unique explanation for these findings, as they can be justified by alternative relationships. First, these results may imply that IMF-supported programmes mechanically compensated with additional conditionality for historically poor performance, either owing to deep-rooted structural weaknesses, persistent shocks, a lack of a reform drive, or a combination of all the above. Without addressing the causes of the past performance, additional conditions would not affect the

\footnotetext{
${ }^{19}$ We did not find, however, any evidence of the so-called Wagner's law - a positive relationship between expenditures and the level of development - in our data.
} 
fiscal performance. Second, IMF conditionality and donor technical assistance in the fiscal area may have failed to bring about sustained fiscal improvements, especially if the reforms were not supported by the public.

To understand better the developments in structural conditionality countries, we re-estimated our regressions for the programme countries only (Table 9) ${ }^{20}$ While the size and signs of the individual coefficients were broadly unchanged compared to Tables 6-8 their statistical significance declined predictably with the loss of degrees of freedom. We found that the overall balance improvement was larger in countries with structural conditionality than in other programme countries by about $1 \frac{1}{2}$ and 3 percentage points of GDP. At the same time, revenue and grants declined by 2 percentage points of GDP more in structural conditionality countries. Finally, the expenditure and net lending compression increased in structural conditionality countries over time - from about 2 percentage points of GDP 1 year after the programme to 8 percentage points of GDP 3 years after the programme - and these results were statistically significant.

We also checked for the presence of fiscal reversals in low-income countries and found this effect to be at work only for the sub-Saharan Africa region. While African countries started with a better-than-average postprogramme overall balance of more than 3 percent of GDP, this result

Table 9: Fiscal developments in structural conditionality countries relative to nonstructural conditionality countries $^{\mathrm{a}}$ (Heteroscedasticity-consistent OLS regression estimates of the structural conditionality and sub-Saharan Africa dummies, $t$-statistics in parentheses)

\begin{tabular}{|c|c|c|c|c|}
\hline & & $\begin{array}{l}\text { Overall } \\
\text { balance }\end{array}$ & $\begin{array}{l}\text { Revenue and } \\
\text { grants }\end{array}$ & $\begin{array}{l}\text { Expenditure and } \\
\text { net lending }\end{array}$ \\
\hline $\begin{array}{l}\text { One-year-after-the-programme } \\
\text { sample }\end{array}$ & $\begin{array}{l}\text { SC dummy } \\
\text { Africa dummy }\end{array}$ & $\begin{array}{l}-0.0018 \\
(0.17) \\
0.0327^{\text {** }} \\
(2.33)\end{array}$ & $\begin{array}{l}-0.0106 \\
(0.72) \\
0.0258^{*} \\
(1.92)\end{array}$ & $\begin{array}{c}-0.0192 \\
(1.15) \\
-0.0116 \\
(0.79)\end{array}$ \\
\hline $\begin{array}{l}\text { Two-years-after-the-programme } \\
\text { sample }\end{array}$ & $\begin{array}{l}\text { SC dummy } \\
\text { Africa dummy }\end{array}$ & $\begin{array}{c}0.0163 \\
(1.28) \\
-0.0035 \\
(0.26)\end{array}$ & $\begin{array}{c}-0.0224^{*} \\
(1.73) \\
0.0203 \\
(1.32)\end{array}$ & $\begin{array}{l}-0.0564 * * * \\
(2.94) \\
0.0229 \\
(1.02)\end{array}$ \\
\hline $\begin{array}{l}\text { Three-years-after-the-programme } \\
\text { sample }\end{array}$ & $\begin{array}{l}\text { SC dummy } \\
\text { Africa dummy }\end{array}$ & $\begin{array}{l}0.0325^{* *} \\
(2.46) \\
-0.0126 \\
(0.54)\end{array}$ & $\begin{array}{l}-0.0286^{* * *} \\
(3.30) \\
0.0565^{* * *} \\
(4.27)\end{array}$ & $\begin{array}{l}-0.0810^{* * *} \\
(4.42) \\
0.0714^{* * *} \\
(3.33)\end{array}$ \\
\hline
\end{tabular}

Source: Authors' estimates.

a The superscripts $* * *, * *$, and * denote the rejection of the null hypothesis that the estimated coefficient is zero at the 1,5 , and 10 percent significance levels, respectively.

${ }^{20}$ The sample sizes for 1-, 2-, and 3-year-after-the-programme regressions were 64, 61, and 49 observations, respectively. The full set of results is available from the authors. 
disappeared in the second year after the end of the programme period. On the expenditure side, the sub-Saharan average was statistically indistinguishable from the rest initially, but by the third year expenditure was 7 percentage points of GDP higher than the average. Revenue performance in sub-Saharan Africa was better than average, although not sufficiently to offset the expenditure increase.

These results seem to suggest that countries with structural conditionality were indeed different from the other programme countries. First, they were subject to more pronounced shocks than other programme countries, for example, their terms of trade were twice as volatile. Second, the effort to address revenue weaknesses in those countries through structural conditionality failed, most likely because conditionality was a poor substitute for homegrown reform. Finally, post-programme fiscal performance in those countries was driven by accelerating expenditure compression, which may not be a bad thing, provided, for example, the pre-programme level of spending was wasteful or that a statist budget was replaced with a less intrusive one.

\section{CONCLUDING REMARKS}

This paper presents empirical tests of the relevance of IMF structural conditionality for post-programme fiscal performance in a large sample of countries during the 1990s. Although the overall balance improved in most countries, the impact of IMF-supported programmes was not statistically significant, owing to the large variance in the sample of programme countries. In structural conditionality countries, revenue declined slightly and expenditure declined significantly. In contrast, in countries that had nonstructural conditionality programmes, revenue remained stable and expenditure increased somewhat. The post-programme statistical insignificance of IMF-supported programmes indicates that programme participation did not make the fiscal adjustment automatically softer - on average, programme countries adjusted as much as nonprogramme countries and fiscal adjustment continued in most countries even after the completion of the IMF-supported arrangement. The business cycle influenced strongly all fiscal variables and an impact of the general macroeconomic stance was detectable as well.

Our results highlight the difficulty in identifying the impact of structural conditionality. Several effects seem to be in play. First, we found some evidence that programmes with too many structural conditions had worse post-programme results than those with fewer programme conditions. Second, 
we found no quantitative evidence that structural conditionality aimed at raising revenue was successful. Third, post-programme expenditure compression clearly was much stronger in countries with structural conditionality, but the risk of reversal was higher too, especially in sub-Saharan Africa.

The findings in this paper are not definitive and the possibilities for further research are extensive. First, more work is needed to examine the role of initial shocks, structural weaknesses, political economy, and regimespecific effects, such as the choice of the exchange rate regime. Second, the policy reaction function can be specified differently, reflecting, for example, policies that would stabilise the debt-to-GDP ratio or that would be based on 'fiscal rules'. Finally, some of the issues, such as the appropriateness of the initial revenue and expenditure levels, cannot be addressed adequately in a cross-country model and need to be investigated in case studies.

\section{REFERENCES}

Abed, GT, Ebrill, L, Gupta, S, Clements, B, McMorran, B, Pellechio, A, Schiff, J and Verhoeven, M. 1998: Fiscal reforms in low-income countries. IMF Occasional paper no. 160, International Monetary Fund: Washington.

Barro, RJ and Lee, J-W. 2002: IMF programmes: Who is chosen and what are the effects? NBER Working paper no. 8951, National Bureau of Economic Research: Cambridge, MA.

Bird, G. 1996: Borrowing from the IMF: The policy implications of recent empirical research. World Development 24(11): 1753-1760.

Bird, G. 2001: IMF programmes: Is there a conditionality laffer curve? World Economics 2(2): 29-49.

Bird, G. 2002: The credibility and signalling effect of IMF programmes. Journal of Policy Modeling 24: 799-811.

Bird, G, Hussain, M and Joyce, JP. 2000: Many happy returns? Recidivism and the IMF. Wellesley College Department of Economics Working paper no. 2000-04 (March).

Bird, G and Rowlands, D. 2002: Do IMF progammes have a catalytic effect on other capital flows? Oxford Development Studies 30(3): 229-249.

Bohn, H. 1998: The behavior of US public debt and deficits. Quarterly Journal of Economics 113: 949-963.

Boughton, JM. 2001: Silent revolution: International monetary fund, 1979-1989. International Monetary Fund: Washington.

Boughton, J and Mourmouras, A. 2002: Is policy ownership an operational concept? IMF Working paper 02/72, International Monetary Fund: Washington.

Bulír, A and Hamann, AJ. 2003: Aid volatility: An empirical assessment. IMF Staff Papers 50(1): 64-89.

Bulír, A and Moon, S. 2003: Do IMF-supported programmes help make fiscal adjustment more durable? IMF Working paper 03/38, International Monetary Fund: Washington.

Bulow, J and Klemperer, P. 1999: The generalized war of attrition. American Economic Review. 89(1): 175-189.

Collier, P, Guillaumont, P, Guillaumont, S and Gunning, JW. 1997: Redesigning conditionality, World Development 25(9): 1399-1407.

Conway, P. 1994: IMF lending programmes: participation and impact. Journal of Development Economics 45(2): 365-91.

Conway, P. 2000: IMF programmes and external balance: the crisis-participation dynamic. [unpublished]. University of North Carolina: Chapel Hill. 
Cottarelli, C and Curzio, G. 2002: Bedfellows, hostages, or perfect strangers? Global capital markets and the catalytic effect of IMF crisis lending. IMF Working paper 02/193, International Monetary Fund: Washington.

Dhonte, P. 1997: Conditionality as an instrument of borrower credibility. IMF paper on policy analysis and assessment 97/2, International Monetary Fund: Washington.

Dicks-Mireaux, L, Mecagni, M and Schadler, S. 2000: Evaluating the effect of IMF lending to low-income countries. Journal of Development Economics 61(2): 495-525.

Dollar, D and Svensson, J. 2000: What explains the success or failure of structural adjustment programmes. Economic Journal 110(466): 894-917.

Drazen, A. 2000: Political economy in macroeconomics. Princeton University Press: Princeton, NJ.

Ghosh, A, Lane, T, Schultze-Ghattas, M, Bulír, A, Hamann, JA and Mourmouras, A. 2002: IMFsupported programmes in capital account crises. IMF Occasional paper no. 210, International Monetary Fund: Washington.

Goldstein, M. 2000: IMF structural programmes. Paper prepared for NBER Conference on Economic and Financial Crises in Emerging Market Economies, Woodstock, Vermont (October).

Goldstein, M, and Montiel, PJ. 1986: Evaluating fund stabilization programmes with multicountry data: Some methodological pitfalls. IMF Staff Papers 33(2): 304-344.

Guitián, M. 1981: Fund conditionality: Evolution of principles and practices, IMF Pamphlet series no. 38, International Monetary Fund: Washington.

Gupta, S, Clements, B, Baldacci, E and Mulas-Granados, C. 2002: Expenditure composition, fiscal adjustment, and growth in low-income countries. IMF Working paper 02/77, International Monetary Fund: Washington.

Hansson, $\AA$ and Stuart, C. 2003: Peaking of fiscal sizes of government. European journal of political economy 19(4): 669-684.

Haque, UN and Khan, MS. 1998: Do IMF-supported programmes work? A survey of the cross-country empirical evidence. IMF Working paper 98/169, International Monetary Fund: Washington.

International Monetary Fund. 1996: Guidelines for Fiscal Adjustment. IMF Pamphlet series no. 49, International Monetary Fund: Washington.

International Monetary Fund. 1998: Financial organization and operations of the IMF. IMF pamphlet series no. 45, International Monetary Fund: Washington.

International Monetary Fund. 2001: Conditionality in fund-supported programs-overview. Available on the Internet at http://www.imf.org/external/np/pdr/cond/2001/eng/overview/index.htm

Ivanova, A, Mayer, W, Mourmouras, A and Anayiotos, G. 2003: What determines the success or failure of fund-supported programmes? IMF Working paper 03/8, International Monetary Fund: Washington.

Khan, MS. 1990: The macroeconomic effects of fund-supported adjustment programmes, IMF Staff Papers 37(2): 195-231.

Khan, MS and Sharma, S, 2001: IMF conditionality and country ownership of programmes. IMF Working paper 01/142, International Monetary Fund: Washington.

Knight, M and Santaella, JA. 1997: Economic determinants of IMF financial arrangements. Journal of Development Economics 54(2): 405-436.

Krueger, AO, 1998: Whither the World Bank and the IMF? Journal of Economic Literature 36: 1983-2020.

Mercer-Blackman, V and Unigotvskaya, A. 2000: Compliance with IMF programme indicators and growth in transition economies. IMF Working paper 00/47, International Monetary Fund: Washington.

Mulligan, CB, Gil, R and Sala-i-Martin, X. 2003: Do democracies have different public policies than nondemocracies? NBER Working paper 10040, National Bureau of Economic Research: Cambridge.

Przeworski, A and Vreeland, JR. 2000: The effect of IMF programmes on economic growth. Journal of Development Economics 62: 385-421. 
Schadler, S, Bennett, A, Carkovic, M, Dicks-Mireaux, L, Mecagni, M, Morsink, JHJ and Savastano, MA. 1995: IMF conditionality: Experience under stand-by and extended arrangements. IMF Occasional paper no. 128, International Monetary Fund: Washington.

Scott, GC. 1996: Government reform in New Zealand. IMF Occasional paper no. 140, International Monetary Fund: Washington.

Tanzi, V and Schuknecht, L. 1997: Reconsidering the fiscal role of government: The international perspective. American Economic Review, Papers and Proceedings 87: 164-168.

Tornell, A and Lane, PR. 1999: The voracity effect. American Economic Review 89(1): 22-46.

World Bank. 2001: Database of Political Institutions, Version 3.0. World Bank; Washington.

Ziegler, KA. 1996: Corruption: The new world disorder. Economic Affairs 16(3): 18-22. 